\title{
ГЛИКОЗИДЫ ФЛАВОНОИДОВ EQUISETUM SILVATICUM L. ХАНТЫ-МАНСИЙСКОГО АВТОНОМНОГО ОКРУГА
}

\author{
() В.М. Боначева", Э.Х. Ботиров \\ Сургутский государственный университет ХМАО - Югры, ул. Ленина, 1, \\ Сургуm, 628412 (Россия), e-mail: bwmbeml@mail.ru
}

\begin{abstract}
Из надземной части Equisetum silvaticum L. (хвощ лесной) семейства Equisetaceae выделены четыре индивидуальных флавоноловых гликозида, которые на основании химических превращений и результатов изучения данных ИК, УФ-, ${ }^{1} \mathrm{H}-Я М Р$ и масс-спектров идентифицированы с кемпферол-3-O- $\beta$-D-глюкопиранозидом, кверцетин-3-O- $\beta$-D-

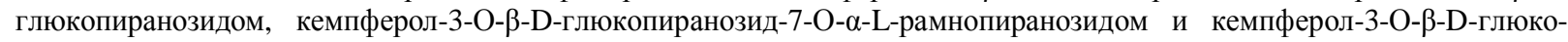

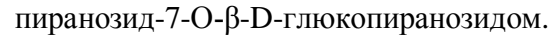

Ключевые слова: Equisetum silvaticum (L.) Smeet - хвощ лесной, флавоноиды, кемпферол, кверцетин, гликозиды, агликон, $\beta$-D-глюкопиранозид, $\alpha$-L-рамнопиранозид.
\end{abstract}

\section{Введение}

Важным направлением в исследовании флавоноидов является создание на их основе лекарственных препаратов, обладающих антиоксидантными, противовоспалительными, гепатопротекторными, антибактериальными и другими полезными свойствами. Такие исследования открывают новые перспективы использования флавоноидов в медицине и фармакологии. И, что очень ценно, такие препараты обладают низкой токсичностью. Многие растения содержат в своем составе соединения фенольной природы. Поэтому большинство представителей флоры на сегодняшний день пользуются повышенным вниманием ученых. Одним из таких растений является Equisetum silvaticum L. (хвощ лесной) [1, 2].

Equisetum silvaticum L. - хвощ лесной - многолетнее травянистое растение семейства Equisetaceae (хвощевые) высотой до 60 см [3, 4]. Имеет тонкое длинное корневище, ползучее, ветвистое. Спороносные побеги рыжеватые или красноватые, с длинными ребрами. Растет во влажных затененных местах: тенистых сырых лесах, кустарниковых зарослях, в ольшанниках, вблизи водоемов, по берегам лесных рек. Избегает почв, богатых известью [5]. Хвощ лесной издавна применяется в народной медицине как мочегонное и вяжущее средство. Биологическая активность компонентов фенольной природы хвоща лесного подтверждена экспериментально. Он обладает антимикробной, диуретической, гепатопротекторной, противовоспалительной, антирадикальной, а также антигрибковой активностью [6].

Хвощ лесной по распространенности, богатым сырьевым ресурсам, а также наличию в нем компонентов фенольной природы является одним из наиболее перспективных для фитохимического изучения растений. За последние годы учеными нашей страны были выделены и изучены некоторые фенольные соединения хвоща лесного. Это гликозиды кемпферола, кверцетина, госсипетина: изокверцетин, кверце-

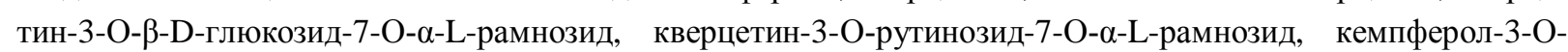

Боначева Виктория Михайловна - аспирант кафедры химии, тел. (3462) 7628 00, факс (3462) 762929 ,

e-mail: bwmbeml@mail.ru

Ботиров Эркин Хожсикбарович - заведующий кафедрой химии, доктор химических наук, профессор, тел.: (3462) 76-30-91, факс: (3462) 76-29-29, e-mail: botirov-nepi@mail.ru

\footnotetext{
* Автор, с которым следует вести переписку.
} рутинозид (никотифлорин) и др. [6]. Фенольные соединения Equisetum silvatucum L. Ханты-Мансийского автономного округа не изучены. Этот факт говорит об актуальности исследований флавоноидов этого растения. 


\section{Экспериментальная часть}

Воздушно-сухое растительное сырье (700 г), заготовленное в 2009 г. на территории Сургутского района, экстрагировали пятикратно при комнатной температуре $85 \%$ этиловым спиртом. Объединенный экстракт сгущали под вакуумом, разбавляли водой в соотношении $1: 1$ и обрабатывали петролейным эфиром, хлороформом, этилацетатом и н-бутанолом. После отгонки растворителей получили 1,8 г хлороформной, 9,5 г этилацетатной и 19,5 г бутанольной фракций. Хроматографированием этилацетатной фракции на колонке $(120 \times 3$ см) с силикагелем (220 г) в градиентной системе «этилацетат - этанол» было получено три соединения. Вещество I (выход 0,3 г) элюировано смесью растворителей «этилацетат - этанол» в соотношении 96 : 4, вещество 2 (0,18 г) - системой «этилацетат - этанол» $(94: 6)$, соединение 3 (0,25 г) - «этилацетат - этанол» $(90: 10)$.

Хроматографированием части бутанольной фракции (12 г) на колонке с силикагелем (240 г) в системе растворителей «этилацетат - этанол» в соотношении $(92: 8)$ получили $(0,4$ г) кемпферол-3-O-7-Одиглюкозида (эквизетрин).

Полученные вещества очищены колоночной хроматографией на полиамиде марки «Woelm» (Германия) в градиентной системе растворителей этилацетат - этанол.

Кислотный гидролиз флавоноидных гликозидов проводили нагреванием на кипящей водяной бане с обратным холодильником раствора 10 мг вещества в 10 мл смеси 5\% соляной кислоты и этанола в соотношении 1:1 в течение 1 ч [7]. Осадок агликона, выпавший при отгонке этанола в вакууме, отделяли фильтрованием. Фильтрат упаривали досуха, остаток растворяли в этаноле и углеводы анализировали методом тонкослойной хроматографии в присутствии подлинных образцов моносахаридов в системе растворителей $н$-бутанол - уксусная кислота - вода (6 : 1,5 : 2,5). Пластинки проявляли смесью $н$-бутанол - вода уксусная кислота - фосфорная кислота - анилин - дифениламин, мл (60 - 25 - 15 - 10 - 1 - 2 г), высушивали в термостате при $120{ }^{\circ} \mathrm{C}$ в течение 5 мин. Значение $\mathrm{R}_{\mathrm{f}} \mathrm{D}$-глюкозы - 0,36, $\mathrm{R}_{\mathrm{f}} \mathrm{L}$-рамнозы - 0,44 [8].

УФ-спектры регистрировали на спектрофотометре Specord M 400 в этаноле, ИК-спектры снимали на ИК-Фурье-спектрометре IR Prestige-21, масс-спектры - на хромато-масс-спектрометре Thermo Finnigan MAT 95 ХР, энергия ионизации 70 эВ. Спектры ${ }^{1} \mathrm{H}-Я М Р$ снимали в ДМСО-d 6 на прибоpe Bruker Avance III c paбочей частотой 500 МГц. Химические сдвиги приведены в миллионных долях (м.д.) в $\delta$-шкале.

Температуры плавления определяли на столике Кофлера.

Для ТСХ использовали пластинки Sorbfil ПТСХ-П-А-УФ. Пятна флавоноидов обнаруживали обработкой пластинок $1 \%$ спиртовым раствором $\mathrm{AlCl}_{3}$. Колоночную хроматографию проводили на силикагеле марки КСК 100/160 мкм.

\section{Обсуждение результатов}

Выделенные индивидуальные соединения относятся к производным флавонолов. Идентифицировали их на основании результатов химических превращений и спектральных данных. Полученные результаты сравнивали с литературными данными.

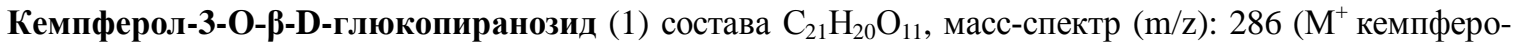
ла), т. пл. 207-209 ${ }^{\circ} \mathrm{C}$. УФ-спектр: $\lambda_{\max } 264,352$ нм; +CH $\mathrm{CH}_{3} \mathrm{COONa:} \mathrm{271,} 371$ нм; + $\mathrm{AlCl}_{3}$ : 273, 408 нм. Изучением УФ-спектров, снятых с добавлением диагностических добавок, установлено наличие свободных фенольных гидроксильных групп в положениях 5, 7, 4' [9, 10]. ИК-спектр $\left(\mathrm{cm}^{-1}\right)$ : 3350-3255 (ОН-группы), 1645 ( $\mathrm{C}=\mathrm{O} \gamma$-пирона), 1618, 1521 (ароматические $\mathrm{C}=\mathrm{C}$ связи), 1114-1062 (С-О связи гликозидов).

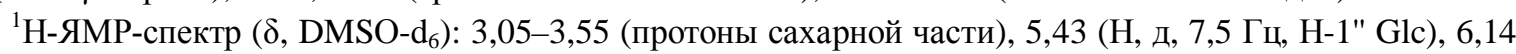
(H, уш.с, Н-6), 6,36 (Н, уш.с, Н-8), 6,86 (2Н, д, 9,0 Гц, Н-3', 5'), 8,00 (2H, 9,90 Гц, Н-2',6'), 12,6 (1Н, уш.с, 5-ОН). Из данных ${ }^{1}$ Н-ЯМР- и ИК-спектров следует, что данное вещество относится к гликозидам.

При кислотном гидролизе этого соединения были получены агликон состава $\mathrm{C}_{15} \mathrm{H}_{10} \mathrm{O}_{6}$, т. пл. 269$271{ }^{\circ} \mathrm{C}, \lambda_{\max } 269,273$ нм и D-глюкоза. Сравнением физико-химических свойств и изучением спектральных данных агликон идентифицировали с кемпферолом [11].

Значение КССВ сигнала аномерного протона D-глюкозы (7,5 Гц) в спектре ${ }^{1} \mathrm{H}$-ЯМР свидетельствует о $\beta$-D-глюкопиранозидной структуре углеводной части.

Обобщая полученные данные, а также сравнивая с подлинным образцом, соединение I идентифици-

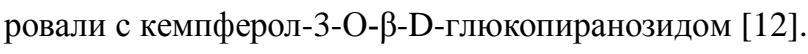

Кверцетин-3-O-ß-D-глюкопиранозид (2) - желтое кристаллическое вещество состава $\mathrm{C}_{21} \mathrm{H}_{20} \mathrm{O}_{12}$, т. пл. 236-238 ${ }^{\circ} \mathrm{C}$. УФ-спектр ( $\lambda_{\max } 264,362$ нм) характерен для 3-О-замещенных флавонолов. Данные УФспектров, снятых с добавлением диагностических реагентов: $+\mathrm{CH}_{3} \mathrm{COONa:} \mathrm{271,} 371 \mathrm{Hм}$; $+\mathrm{AlCl}_{3}$ : 273, 
408 нм; +NaOH: исчезновение полосы II, общее понижение интенсивности поголощения [13]. ИК-спектр $\left(\mathrm{cm}^{-1}\right)$ : 3350-3256 (ОН-группы), 1645 ( $\mathrm{C}=\mathrm{O}$-пиирона), 1115-1061 (С-О связи гликозида). В массспектре пик иона $\mathrm{c} \mathrm{m} / \mathrm{z} 302$ соответствует молекулярному иону агликона кверцетина.

${ }^{1} \mathrm{H}$-ЯМР-спектр ( $\delta$, DMSO-d $)$ ) 3,06-3,54 (протоны сахарной части), 5,44 (1Н, д, 7,3 Гц, Н-1" аномер H-Glc), 6,14 (1Н, д, 1,8 Гц, Н-6), 6,34 (1H, д, 1,8 Гц, Н-8), 6,81 (1Н, д, 9,0 Гц, Н-5'), 7,56 (2H, дд, 2,1 и 9,00 Гц, Н-2', 6'), 12,6 (1Н, уш.с, 5-ОН). По данным ИК- и ${ }^{1}$ Н ЯМРспектров данное соединение является гликозидом.

При кислотном гидролизе соединения 2 были получены агликон кверцетин и D-глюкоза [11].<smiles>[R20]Oc1cc(O)c2c(=O)c(O[Z10])c(-c3ccc(O)c([R])c3)oc2c1</smiles>

1. $R_{1}=\beta$-D-Glcp, $R_{2}=R_{3}=H$

2. $\mathrm{R}_{1}=\beta$-D-Glcp, $\mathrm{R}_{2}=\mathrm{H}, \mathrm{R}_{3}=\mathrm{OH}$

3. $\mathrm{R}_{1}=\beta$-D-Glcp, $\mathrm{R}_{2}=\alpha$-L-Rhap, $\mathrm{R}_{3}=\mathrm{H}$

4. $\mathrm{R}_{1}=\mathrm{R}_{2}=\beta-\mathrm{D}-$ Glcp, $\mathrm{R}_{3}=\mathrm{H}$

На основании изучения спектральных данных и результатов кислотного гидролиза, а также сравнением с подлинным образцом соединение 2 идентифицировали с кверцетин-3-O- $\beta$-D-глюкопиранозидом [13].

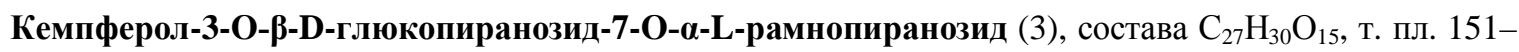
$153{ }^{\circ} \mathrm{C}$, масс-спектр (m/z): $286\left(\mathrm{M}^{+}\right.$агликона кемпферола). УФ-спектр соединения $\left(\lambda_{\max } 272,359\right.$ нм) характерен для 3-О-замещенных флавонолов [9]. При снятии УФ-спектра в присутствии диагностических добавок получены следующие результаты: $+\mathrm{CH}_{3} \mathrm{COONa:} \mathrm{272,} 359$ нм (ОН в положении 7 замещена) [13]; +NaOH: 273, 399 нм; $+\mathrm{AlCl}_{3}: 272,348,400$ нм.

ИК-спектр (см $\left.{ }^{-1}\right):$ 3358-3304 (ОН-группы), 2852, 2922 (С-С связи углеводной части), $1649(\mathrm{C}=\mathrm{O}$ $\gamma$-пирона), 1058-1002 (С-О связи гликозида) и др.

${ }^{1} \mathrm{H}$-ЯМР-спектр ( $\delta$, DMSO-d 6 ): 1,10 (д, 6 Гц, $\mathrm{CH}_{3}$-рамнозы), 3,02-3,85 (м, протоны углеводной части), 5,34 (д, 7,3 Гц, Н-1"' аномер H-Glc), 5,55 (уш. с, H-1" аномер H-Rha), 6,42 (1Н, д, 1,7 Гц, Н-6), 6,76 (уш.с, Н-8), 6,86 (2Н, д, 8,1 Гц, Н-3', Н-5'), 8,00 (2Н, д, 8,1 Гц, Н-2', Н-6'), 12,50 (уш.с, 5-ОН). Спектр ${ }^{1}$ Н-ЯМР вещества 3 содержит сигналы протонов 3,7-ди-О-замещенного кемпферола.

При кислотном гидролизе гликозида 3 получили кемпферол и моносахариды D-глюкозу и L-рамнозу. Сравнивая УФ-спектры кемпферола и гликозида, можно сделать вывод о замещенной 3-ОН-группе.

Таким образом, полученные данные позволяют идентифицировать соединение 3 с кемпферол-3-O- $\beta$ D-глюкопиранозид-7-O- $\alpha-\mathrm{L}-$ рамнопиранозидом [14].

Кемпферол-3,7-ди-О-ß-D-глюкопиранозид (4) - светло-желтое кристаллическое вещество состава $\mathrm{C}_{27} \mathrm{H}_{30} \mathrm{O}_{16}$, т.пл. $163-165{ }^{\circ} \mathrm{C}$, масс-спектр (m/z): 286 (M ${ }^{+}$агликона кемпферола) . УФ-спектр вещества имеет полосы поглощения при $\lambda_{\max } 272,359$ нм, что характерно для 3-О-замещенных флавонолов [11]. + $\mathrm{CH}_{3} \mathrm{COONa}: 272,359$ нм (7-OH группа замещена) [13]; +NaOH: 272, 368 нм; + $\mathrm{AlCl}_{3}: 276,349,401 \mathrm{нм.}$

ИК-спектр (см $\left.{ }^{-1}\right)$ : 3389-3088 (ОН-группы), 2737 (С-С связи углеводной части), 1649 (С=О $\gamma$-пирона), 1096, 1066, 1028 (С-О связи гликозида) и др.

${ }^{1} \mathrm{H}$-ЯМР-спектр ( $\delta$, DMSO-d $)$ ) 3,05-3,55 (протоны сахарной части), 5,45 (Н, д, 7,4 Гц, Н-1"' аномер H-Glc), 5,52 (Н, д, 7,9 Гц, Н-1" аномер H-Glc), 6,78 (1Н, уш.c, Н-6), 6,86 (1Н, д, 3 Гц, Н-8), 7,54 (2H, д, 9,5 Гц, Н-3',5'), 8,05 (2Н, дд, 7,4 Гц и 9,5 Гц, Н-2',6'), 12,60 (1Н, уш.с, 5-ОН). В ПМР-спектре наблюдается сигналы двух аномерных протонов, что свидетельствует о наличии двух остатков углевода. При кислотном гидролизе вещества (4) были получены кемпферол и D-глюкоза.

Сравнительное изучение спектральных данных и физико-химических свойств с литературными сведениями позволило идентифицировать вещество 4 с кемпферол-3,7-ди-O- $\beta$-D-глюкопиранозидом (эквизетрином) [15].

\section{Bыводы}

1. Из надземной части хвоща лесного выделены известные флавоноиды: кемпферол-3-O- $\beta$-Dглюкопиранозид, кверцетин-3-O- $\beta$-D-глюкопиранозид, кемпферол-3-O- $\beta$-D-глюко-пиранозид-7-O- $\alpha-\mathrm{L}-$ рамнопиранозид и кемпферол-3,7-ди-О- $\beta$-D-глюкопиранозид.

2. Выделенные соединения идентифицированы на основании результатов химических превращений, данных УФ-, ${ }^{1} \mathrm{H}-Я М Р-$, ИК- и масс-спектров. 


\title{
Список литературы
}

1. Middleton E., Kandaswami C., Theoharis C.T. The Effects of Plant Flavonoids on Mammalian Cells: Implications for Inflammation, Heart Dislase, and Cancer // Pharmacol. Rev. 2000. Vol. 52. Pp. 673-751.

2. Кугач В.В., Никульшина Н.И., Ищенко В.И. Лекарственные формы флавоноидов // Химико-фармацевтический журнал. 1988. Т. 22. С. 1018-1025.

3. Соколов С.Я., Замотаев И.П. Справочник по лекарственным растениям. М., 1985. 463 с.

4. Носов А. Лекарственные растения. М., 2001. 348 с.

5. Шамрук С.Г. Лекарственные растения. М., 1989. 286 с.

6. Коломиец Н.Э., Калинкина Г.И. Сравнительное исследование химического состава видов рода флоры Сибири // Химия растительного сырья. 2010. №1. С. 149-154.

7. Chander R.F., Harpek K.A. Identification of Saccharides in Anthcyanins and other Flavonoids // Austral. J. Chem. 1961. Vol. 14. N4. Pp. 586-595.

8. Методы исследования углеводов / пер. с англ. В.А. Несмеянова ; под ред. А.Я. Хорлина. М., 1975. 445 с.

9. Markham K.R. Techniques of Flavonoid Identification. London, 1982. 113 p.

10. Mabry T.I., Markham K.R., Thomas M.B. The Systematic Identification of Flavonoids. New-York, 1970. 354 p.

11. Корулькин Д.Ю., Абилов Ж.А., Музычкина Р.А., Толстиков Г.А. Природные флавоноиды. Новосибирск, 2007. 232 с.

12. Ковганко Н.В., Кашкан Ж.Н., Кривенко С.М. Астрагалин из Artemisia subterrarium // Химия природных соединений. 2002. №3. С. 274-275.

13. Yuldashev M.P., Muminova B.A., Drenin A.A., Botirov E.Kh. Flavonoids from the aerial Part of Vicia subvillosa // Chem. Nat. Comp. 2007. Vol. 43, N1. Pp. 34-36.

14. Keiko Yonekura-Sakakibara, Takayuki Tohge, Rie Niida and Kazuki Saito. Identification of a Flavonol 7-ORhamnosyltransferase Gene Determining Flavonoid Pattern in Arabidopsis by Transcriptome Coexpression Analysis and Reverse Genetics // Biological Chemistry. 2007. N2. P. 282.

15. Filippo Imperato. Flavonol glycosides from Asplenium bulbiferum // Phytochemistry. 1985. Vol. 24, N9. Pp. $2136-2137$.

Поступило в редакцию 18 мая 2012 г.

\begin{abstract}
Bonacheva V.M. ${ }^{*}$, Botirov E.Kh. GLYCOSIDES FLAVONOIDS EQUISETUM SILVATICUM L. SMEET HUNTSMANSIJSKOGO OF AUTONOMOUS REGION

Surgut State University, Lenina st., 1, Surgut, 628412 (Russia),e-mail: bwmbeml@mail.ru

The article is devoted to the phytochemical study of Glycosides flavonoids Equisetum silvaticum (L.) Smeet . From the overgrown part of Equisetum silvaticum (L.) Smeet flavonoids kaempferol-3-O- $\beta$-D-glucopyranoside, quercetin-3-O- $\beta$-Dglucopyranoside, kaempferol-3-O- $\beta$-D-glucopyranoside-7-O- $\alpha$-L-ramnopyranoside, kaempferol-3-O- $\beta$-D-glucopyranoside-7O- $\beta$-D-glucopyranoside were isolated. The resulting compounds were identified on the basis of results of chemical transformations and IR, UV, 1H-, 13C-NMR and mass spectra.
\end{abstract}

Keywords: Equisetum silvaticum L. Smeet, flavonoids, kaempferol, quercetin, aglycone, $\beta$-D-glucopyranoside, $\alpha$-Lramnopyranoside.

\section{References}

1. Middleton E., Kandaswami C., Theoharis C.T. Pharmacol. Rev., 2000, vol. 52, pp. 673-751.

2. Kugach V.V., Nikul'shina N.I., Ishchenko V.I. Khimiko-farmatsevticheskii zhurnal, 1988, vol. 22, pp. 1018-1025. (in Russ.).

3. Sokolov S.Ia., Zamotaev I.P. Spravochnik po lekarstvennym rasteniiam. [Handbook of Medicinal Plants]. Moscow, 1985, 463 p. (in Russ.).

4. Nosov A. Lekarstvennye rasteniia. [Drug plants]. Moscow, 2001. 348 p. (in Russ.).

5. Shamruk S.G. Lekarstvennye rasteniia. [Drug plants]. Moscow, 1989. 286 p. (in Russ.).

6. Kolomiets N.E., Kalinkina G.I. Khimiia rastitel'nogo syr'ia, 2010, no. 1, pp. 149-154. (in Russ.).

7. Chander R.F., Harpek K.A. Austral. J. Chem., 1961, vol. 14, no. 4, pp. 586-595.

8. Metody issledovaniia uglevodov / pod red. A.Ia. Khorlina. [Methods for studying carbohydrate. Ed. A.J. Khorlin.]. Moscow, 1975, 445 p. (in Russ.).

9. Markham K.R. Techniques of Flavonoid Identification. London, 1982. 113 p.

10. Mabry T.I., Markham K.R., Thomas M.B. The Systematic Identification of Flavonoids. New-York, 1970. 354 p.

11. Korul'kin D.Iu., Abilov Zh.A., Muzychkina R.A., Tolstikov G.A. Prirodnye flavonoidy. [Natural flavonoids]. Novosibirsk, 2007. 232 p. (in Russ.).

12. Kovganko N.V., Kashkan Zh.N., Krivenko S.M. Khimiia prirodnykh soedinenii, 2002, no. 3, pp. 274-275. (in Russ.).

13. Yuldashev M.P., Muminova B.A., Drenin A.A., Botirov E.Kh. Chem. Nat. Comp., 2007, vol. 43, no. 1, pp. 34-36.

14. Keiko Yonekura-Sakakibara, Takayuki Tohge, Rie Niida and Kazuki Saito. Biological Chemistry, 2007, no. 2, p. 282.

15. Filippo Imperato. Phytochemistry, 1985, vol. 24, no. 9, pp. 2136-2137.

\footnotetext{
* Corresponding author.
} 